\title{
PATTERNS OF METACOGNITIVE AWARENESS AMONG PRIMARY SCHOOL TEACHERS
}

\author{
N.John Palantis@ Johan, A. Mohamed, A.S. Mohd Ibrahim, S.H. Ismail, N.K. Anuar, \\ A.M. Ma'rof, N.Buang \\ Faculty Educational Studies, University of Putra Malaysia \\ norazirahbuang@gmail.com
}

\begin{abstract}
The purpose of this study is to identify level and patterns of metacognitive awareness among teachers in primary schools. This study focuses on aspects of declarative knowledge, procedural knowledge, conditional knowledge, planning, monitoring and evaluation of teachers. The study was descriptive in nature. A sample of 100 primary school teachers in Puchong, Selangor answered the Metacognitive Awareness Inventory for Teacher by Cem Balcikanli (2011). The data analysis was carried out using IBM Statistics version 24 to obtain descriptive measures. The results show that levels of metacognitive awareness among teachers are high at ninety three percent (93\%). The results also show that there are no significant differences by gender, age, teaching experience, academic qualification and subject of teaching among primary school teachers. The metacognitive framework shows that metacognition knowledge and regulatory expertise were used by individuals to control their cognition. Teachers who have a higher level of metacognitive awareness can produce students with good academic achievement.
\end{abstract}

Keywords: Metacognitive awareness, declarative, planning, knowledge, academic achievement

\section{Introduction}

In the late 1970s, the word metacognitive was coined by John Flavell (1979) which defines the phenomenon of thinking your own thinking (Lai, 2011). Flavell defines metacognition as the knowledge of cognition and active observation, control and regulate cognitive process (Wen \& Ya-Hui). It also refers to the individual ability to choose the best thinking strategy to complete a challenge. Flavell suggests that metacognition requires at least two components to happen during the thinking process. The first component is the skill mastery where a good thinker is aware of the metacognition by self-reflecting effectively. Second component is the skill to manage the thinking independently by applying the correct strategy at the correct time (Gopinath, 2014). Brown (1978) have conducted many follow up studies and focuses more on the problems and information understanding. $\mathrm{He}$ defines metacognition as the self-awareness and good mental management in learning and solving problems. He supports the definition by referring to an individual's knowledge and mastery on his own cognitive system (Wen \& Ya-Hui). Brown believe there two factors that should be taken into account in defining metacognition. Stat able and stable in metacognition is the first factor.

The other one is the cognitive activity regulations (Palinscar \& Brown, 1987). According to Balcikanli (2011), the spectrum of metacognitive can be divided into six categories. Those are procedure knowledge, declarative knowledge, conditional knowledge, strategy, assessment, and observation. Good mental manager will weigh in these conditions in his thinking process to keep on mastering the strategies. Metacognitive is often interpreted as the higher order of thinking skill. HOTS are well associated with Bloom's Taxonomy. Applying 
Bloom's Taxonomy promotes higher order thinking skills among students (Zohar 1999). Teachers are encouraged to promote these skills in order to expose students to exceed the Understanding level of the taxonomy. Stimulations are needed to achieve the Apply, Analyze, Assess, Synthesize stages. Reading and memorizing content are not the only factors in HOTS (King, Ludwika \& Rohani 2014).

Abdullah \& Khairuddin (2012) are on the same page with the experts in metacognitive who believe that the main objective of learning is to expand the higher order thinking skill. This ability then enforced by preparing questions and training in solving problems based on the student's metacognitive levels. Arends (2008) in Abdullah, Malago, Bundu \& Thalib (2013) stated that metacognitive is the application of the procedural knowledge in solving real life problems or cognitive conflicts. HOTS demand a logical, critical, and reflective metacognition. Zohar 2014 stated there are four sub-categories thinking skills dimension in which one of it defines metacognition as thinking about your own thinking (Yen \& Halili 2015).

In educational context, Perfect and Schwartz 2002 states metacognition is often applied in such understanding where when a student is able to regulate the way of his thinking, the student will always improve and grow. According to Harskamp and Henry 2009, there are many definition and interpretation on metacognition, however, the policy maker in education believe if the students are trained to apply metacognitive skills, the students are expected to become more self-regulated (Michelle, 2012). Recently, researches have been made on teachers thinking. The results indicated a teacher by profession must possess good decision making skill and a reflective thinker. Teachers should not solely focus in content dissemination alone; they are required to actively make decisions during teaching and learning, to make sure the objectives can be achieved. These skills are polished through experience and training. Metacognition is vital in improving the career as an educator. Application of metacognitive in the planning, observing and assessing of students helps by having a great strategy to address the student's problem accurately.

\section{Method}

\section{A. Participants}

The research design in this study is a descriptive survey method. The study was conducted by a selection of school in Puchong, Selangor. The population in this study is 100 primary school teachers in Puchong. The sample of the study 120 respondents from two schools through simple random sampling

\section{B. Instruments}

The instrument used for study is the Teachers Metacognitive Awareness Inventory for Teachers by Cem Balcikanli (2012). The instruments consist of 24 items which are split into six subscales: declarative knowledge, procedural knowledge, conditional knowledge, planning, monitoring and evaluating. The instrument was standardized and its validity was determined by the authors

\section{Procedures}

The instrument have two sections which the first section is demography part including teachers demography. The second section will include metacognitive awareness inventory for teacher which has six subscales

\section{Validity and the reliability}

The reliability coefficients of the questionnaire for internal consistency were determined. The result of reliability shown alpha cronbach is .894 .

\section{E. Data analysis procedure}

Percentage, mean, standard deviation, t-test and ANOVAs will be conducted upon completion of data collection. 


\section{Result}

\section{Demographic respondent}

Table 1 show female teachers have higher distribution compared to the male teachers. The age and teaching experience distribution of the sample is in accordance of the general population. Meanwhile for academic qualification, most teachers are degree holder with less than ten years of experience in teaching.

Table 1 Demographic characteristics

\begin{tabular}{llc}
\hline & & $\mathrm{N}$ \\
\hline \multirow{2}{*}{ Gender } & Male & 42 \\
& Female & 58 \\
& $21-30$ & 39 \\
Age & $31-40$ & 46 \\
& $41-50$ & 13 \\
& $51-60$ & 2 \\
Teaching experience & & \\
& $<5$ & 41 \\
& $5-10$ & 43 \\
Academic qualification & $11-15$ & 12 \\
& $15-20$ & 1 \\
& $>20$ & 3 \\
& & 3 \\
& Diploma & 85 \\
& Degree & 12 \\
& Master & \\
& & 33 \\
& Bahasa Melayu & 29 \\
& English & 17 \\
& Mathematic & 21 \\
\hline & Science &
\end{tabular}

\begin{tabular}{lcc}
\multicolumn{3}{c}{ Table 2: Level of metacognitive awareness } \\
\hline \multicolumn{1}{c}{ Level } & Frequency & Percent (\%) \\
\hline Low & 1 & $1 \%$ \\
Moderate & 6 & $6 \%$ \\
Higher & 93 & $93 \%$ \\
\hline
\end{tabular}

Table 3: Metacognitive awareness by gender

\begin{tabular}{lllllll}
\hline \multicolumn{1}{c}{ Gender } & N & Min & Sd & t & df & Sig \\
\hline Male & 42 & 4.211 & .165 & 1.352 & 98 & .179 \\
Female & 58 & 4.114 & .439 & & & \\
\hline
\end{tabular}

\section{Level of metacognitive awareness}

Table 2 summarizes the level of metacognitive awareness among primary school teachers. The results show the respondents possess higher level of metacognitive awareness at $93 \%$.

\section{Metacognitive awareness by gender}

Table 3 summarizes the differences among genders toward metacognitive awareness. There is no significant difference of metacognitive level of awareness between the two genders $(\mathrm{p}>0.05)$.

\section{Metacognitive awareness by age}

Table 4 summarizes level of difference toward metacognitive awareness by age. There is no significant level of differences toward metacognitive awareness between age $(p>0.05)$. 
Table 4: Metacognitive awareness by age

\begin{tabular}{lccccc}
\hline & Sum of Squares & df & Mean Square & F & Sig \\
\hline Between Groups & .356 & 3 & .119 & .951 & .419 \\
Within Groups & 11.997 & 96 & .125 & & \\
Total & 12.354 & 99 & & & \\
\hline
\end{tabular}

Table 5: Metacognitive awareness by academic qualification

\begin{tabular}{lccccc}
\hline & Sum of Squares & df & Mean Square & F & Sig \\
\hline Between Groups & .034 & 2 & .017 & .134 & .875 \\
Within Groups & 12.320 & 97 & .127 & & \\
Total & 12.354 & 99 & & & \\
\hline
\end{tabular}

Table 6: Metacognitive awareness by subject of teaching

\begin{tabular}{lccccc}
\hline & Sum of Squares & df & Mean Square & F & Sig \\
\hline Between Groups & .254 & 3 & .085 & .6 .73 & .571 \\
Within Groups & 12.099 & 96 & .126 & & \\
Total & 12.354 & 99 & & & \\
\hline
\end{tabular}

Table 7: Metacognitive awareness by teaching experience

\begin{tabular}{lccccc}
\hline & Sum of Squares & df & Mean Square & F & Sig \\
\hline Between Groups & .688 & 4 & .172 & 1.401 & .240 \\
Within Groups & 11.666 & 95 & .123 & & \\
Total & 12.354 & 99 & & & \\
\hline
\end{tabular}

8. Metacognitive awareness by academic qualification

Table 5 summarizes the level of differences toward metacognitive awareness by academic qualifications. There is no significant difference in the level of metacognitive awareness between academic qualification $(\mathrm{p}>0.05)$.

\section{Metacognitive awareness by subject of teaching}

Table 6 summarizes the level of differences toward metacognitive awareness by subject of teaching. There is no significant difference in the level of metacognitive awareness between subject of teaching $(\mathrm{p}>0.05)$.

\section{Metacognitive awareness by teaching experience}

Table 7 summarizes the level of differences toward metacognitive awareness by the years of teaching experience. There is no significant difference in the level of metacognitive awareness between years of teaching experience $(p>0.05)$.

\section{Discussion}

The result has shown the level of metacognitive awareness among the teachers as high. There is not a single significant difference found from the results of the study. There are several possible reasons to explain this phenomenon. The first one would be the size of the population of the survey. A larger population may produce a less predictable result, if not different. Therefore, future study may need to consider performing the study with a larger population and sample.

Secondly, the study was performed only in one school. The school is located in an urban area and have a decent background herself. The school (students and teachers) is under the jurisdiction of Jabatan Pelajaran Negeri Selangor, which is one of the top performers in national examinations. We believe the 
teachers are given adequate training at the district as well as state level to polish the quality of their teachings, thus explaining the metacognitive awareness among them although there might be no independent effort made by the teacher themselves. Therefore, a study done across the districts in Selangor which include the rural and suburban schools may produce different results.

Lastly, the socioeconomic status of the students' family might influence the result produced from the study. There are at least three types of groups exist in a school setting which are the administrators, teachers and students. Being in an urban area, the students are exposed to endless opportunities and amenities to learn and grow within the community. Students in rural and suburban areas do not enjoy the same benefit although they are populating the same state. Although a study is needed to support this claim, but the teachers might not need to go to a greater mileage in teaching the students. Most of the students in the school, if not all, may have enrolled in private tutors just to make the job of their teacher less challenging. A teacher in the outskirts of Sabak Bernam might have trouble to apply conventional teaching to the less-privileged students. Therefore, the awareness level of metacognitive in that particular school may differ due to several factors especially the teacher's motivation.

\section{Conclusion}

The importance of metacognition mastery has heavily influences us to perform this study. Malaysian law has stated that all of her citizens to be enrolled in school at certain age until certain age. This is a clear indication on the importance of education in building a nation. Teachers and educators are the pillars if the nation is taken as a building. Without undermining our educational system, it is undeniable that metacognitive skills are left out in pursuing the national assessments glory. The lessons and contents are disseminated directly to the students as preparations of tests and examinations. Key critical thinking components such as the higher order of thinking skills have become elusive even irrelevant in generating beautiful assessments statistics in school. Teachers and tutors have invested heavily in finding a holy grail or the perfect formula to obtain in examinations. Therefore, this study is intended to provide an opportunity to the educators to change or improve their approaches in the classroom. A teacher who masters the metacognition skills will not be stagnant in their lessons and active in catering each of her students.

\section{References}

Abdullah, H., Malago,J. D., Bundu,P.,\& Thalib,S.B. (2013). The use of Metacognitive Knowledge Patterns to Compose Physics Higher Order Thinking Problems: Asia Pacific Forum on Science Learning and Teaching, 14(2), 1.

Abdullah, H. \& Khaeruddin (2012). Study on Metacognitive Knowledge in Student Physics Education Program, State University of Makassar. Makassar: Lembaga Penelitian UNM.

Ahmet, Ismail (2011). Literature Review on Metacognition and its Measurement. Procedia Social and Behavioral Sciences, 15(1), 3731-3736.

Arends, R.I. (2008). Learning To Teach. (7 th $^{\text {ed. }}$. . NewYork: Mc.Graw Hill Companies, Inc.

Balcikanli, C. (2011). Metacognitive awareness inventory for teachers (MAIT). Electronic Journal of Research in Educational Psychology, 9(3), 1309-1332.

Brown, A. L. (1978) "Knowing when, where, and how to remember: A problem of metacognition" in R.Glaser (Eds.), Advances in instructional psychology (Vol.1, pp. 77$165)$. 
Brown, A. L. \& Palincsar, A. S. (1987). Reciprocal teaching of comprehension strategies: A natural history of one program for enhancing learning. In J. Day \& J. Borkowski (Eds.), Intelligence and exceptionality: New directions in theory, assessment and instructional practices (pp. 81-132).

Flavell, J. H. (1979). Metacognition and cognitive monitoring: A new area of cognitive developmental inquiry. American Psychologist, 34(10), 906-911.

Gopinath, S. (2014). Metacognitive awareness in Teaching and Teaching Competency: A Survey on Student Teachers at Secondary Level. Research and Method on education, 4(4), 33-35.

Harskamp, E. G., \& Henry, D. (2009). Introduction to this special issue. Educational Research and Evaluation. 15(5), 429.

King, FJ, Ludwika, G.,Rohani, F. (2014). Statewide assessment of listening and verbal communication skills, information literacy skills, and problem-solving skills. Tallahassee: Florida State University.

Lai, E. R. (2011). Metacognition. A Literature Review. Pearson Research Reports. Retrieved from http://www.pearsonassessments.com

Michelle, P.P. (2012). Teacher Metacognition within the Professional Learning Community. International Education Studies, 5(4), 112-121.

Perfect, T.J and Schwartz, B. L. (2002). Applied Metacognition. Cambridge University Press: United Kingdom.

Wen, Ya-Hui (2012). A Study on Metacognition of College Teachers. The Journal of Human Resource and Adult Learning, 8(1), 80-91.

.Yen, T. S., \& Halili, S. H. (2015). Effective teaching of Higher-Order Thinking (HOT) in Education. The Online Journal of Distance Education and E-Learning, 3(2), 41-47.

Zohar, A. (2013). A Review of Research on Metacognition in Science Education: Current and Future Directions. Studies in Science education, 49(2), 121-169.

Zohar, A. (1999). Teachers' metacognitive knowledge and the instruction of higher order thinking. Teaching and Teacher Education, 15(1), 413-429. 